medRxiv preprint doi: https://doi.org/10.1101/2020.05.29.20114751; this version posted June 2, 2020. The copyright holder for this preprint (which was not certified by peer review) is the author/funder, who has granted medRxiv a license to display the preprint in perpetuity. All rights reserved. No reuse allowed without permission.

\title{
Syncope at SARS-CoV-2 onset due to impaired baroreflex response
}

Ciro Canetta, ${ }^{1}$ Silvia Accordino, ${ }^{1}$ Elisabetta Buscarini, ${ }^{2}$ Gianpaolo Benelli, ${ }^{3}$ Giuseppe La Piana, ${ }^{4}$ Alessandro Scartabellati, ${ }^{5}$ Giovanni Viganò, ${ }^{6}$ Roberto Assandri, ${ }^{7}$ Alberto Astengo ${ }^{8,9}$ Chiara Benzoni, ${ }^{8,9}$ Gianfranco Gaudiano, ${ }^{8,9}$ Daniele Cazzato, ${ }^{10}$ Davide Sebastiano Rossi, ${ }^{10}$ Susanna Usai, ${ }^{9}$ Irene Tramacere ${ }^{11}$, and Giuseppe Lauria $^{8,9}$

${ }^{1}$ Emergency Medicine Unit, ${ }^{2}$ Gastroenterology Unit, ${ }^{3}$ Radiology Unit, ${ }^{4}$ Pneumology 2 Unit, ${ }^{5}$ Pneumology 1 Unit, ${ }^{5}$ Emergency Unit and ${ }^{7}$ Clinical Investigation Laboratory, Ospedale Maggiore di Crema, Crema, Italy; ${ }^{8}$ Department of Biomedical and Clinical Sciences "Luigi Sacco", University of Milan, Milan, Italy; ${ }^{9}$ Department of Clinical Neurosciences, ${ }^{10}$ Department of Diagnostics and Technology, ${ }^{11}$ Scientific Directorate, Fondazione IRCCS Istituto Neurologico "Carlo Besta", Milan, Italy

Corresponding Author:

Giuseppe Lauria, MD

Department of Biomedical and Clinical Sciences "Luigi Sacco", University of Milan

Department of Clinical Neuroscience, IRCCS Foundation "Carlo Besta" Neurological Institute Milan, Italy 
medRxiv preprint doi: https://doi.org/10.1101/2020.05.29.20114751; this version posted June 2, 2020. The copyright holder for this preprint

(which was not certified by peer review) is the author/funder, who has granted medRxiv a license to display the preprint in perpetuity.

All rights reserved. No reuse allowed without permission.

\begin{abstract}
We describe clinical and laboratory findings in 35 consecutive patients tested positive for SARS-CoV-2 by reverse transcriptase-polymerase chain reaction on nasopharyngeal swab that presented one or multiple syncopal events at disease onset. Neurological examination and electrocardiographic findings were normal. Chest computed tomography showed findings consistent with interstitial pneumonia. Arterial blood gas analysis showed low $\mathrm{pO} 2, \mathrm{pCO} 2$, and $\mathrm{P} / \mathrm{F}$ ratio indicating hypocapnic hypoxemia, while patients did not show the expected compensatory heart rate increase. Such mechanism could have led to syncope. We speculate that SARS-CoV-2 could have caused angiotensin-converting enzyme-2 (ACE2) receptor internalization in the nucleus of the solitary tract (NTS), thus altering the baroreflex response and inhibiting the compensatory tachycardia during acute hypocapnic hypoxemia.
\end{abstract}

Keywords: SARS-CoV-2; syncope; hypocapnic hypoxemia; angiotensin-converting enzyme-2 (ACE2) receptor; baroreceptor reflex.

Since the beginning of the severe acute respiratory syndrome coronavirus 2 (SARS-CoV-2) pandemic in Italy on February $19^{\text {th }}, 2020$, the Lombardy Region in Northern Italy has been one the most affected areas in Europe. The public hospital in the town of Crema was one of the first to face the exponential influx of patients. Thanks to the immediate adoption of available local procedures to cope with the hospitalization of patients with a potential viral spread, based on 2009 SARS and H1N1 pandemic strategic plan revised on December 2014 after Ebola outbreak, the Emergency Department could set up a standardized triage for any individual either reporting or presenting with fever, cough, or dyspnea, or having had contact with potentially Covid-19 carriers.

\title{
METHODS
}

Since February $21^{\text {th }}$, all consecutive suspected patients admitted to the hospital underwent a procedure including body temperature and pulse oximetry $(\mathrm{SO} 2)$ recording, hematological screening, chest $\mathrm{X}$-ray and/or computed tomography (CT) scan, and nasopharyngeal swab. Swabs were stored $a t+4^{\circ} \mathrm{C}$ and immediately shipped to one of the laboratory of virology accredited by the Lombardy Region to perform diagnostic SARS-COV-2 real-time polymerase chain reaction (RT-PCR) assay. Based on the clinical, laboratory, and radiological findings, patients were discharged to home in quarantine or admitted to the hospital. All necessary patient consent has been obtained and the appropriate institutional forms have been archived.

Recently, some case series have reported syncope as the first manifestation of SARS-CoV-2 infection, even in the absence of other common symptoms such as fever, cough, and dyspnea. Patients had in common comorbidities for heart disease, coronary artery disease, post-permanent pacemaker (PPM) or cardiac loop recorder implantation (Ebrille et al., 2020; Tape et al., 2020). We analyzed 411 consecutive patients tested positive for SARS-CoV-2 by reverse transcriptase-polymerase chain reaction at nasopharyngeal swab among whom nearly $10 \%$ reported syncope at the onset of the infection (Benelli et al., 2020). Herewith we describe clinical and laboratory findings in 35 consecutive patients that presented one or multiple (9 patients; $25.7 \%$ ) syncopal events at disease onset.

Syncope occurred within $3.6 \pm 2.7$ days from hospital admission. Nine $(25.7 \%)$ patients reported head trauma and one subdural haemorrhage. Associated onset symptoms were fever $>37.5^{\circ} \mathrm{C}$ in $17(48.5 \%)$ patients, cough in $8(22.8 \%)$, and dyspnoea in $7(20 \%)$. Hypertension (45.7\%), dyslipidaemia (17\%), renal insufficiency, hypothyroidism, dementia, cancer (8.5\%), anaemia and atrial fibrillation (5.7\%) were the most 
medRxiv preprint doi: https://doi.org/10.1101/2020.05.29.20114751; this version posted June 2, 2020. The copyright holder for this preprint

(which was not certified by peer review) is the author/funder, who has granted medRxiv a license to display the preprint in perpetuity.

All rights reserved. No reuse allowed without permission.

common comorbidities. Twenty-one (60\%) patients reported intake of $>3$ drugs, 12 (34.3\%) of 4-6 drugs and $2(5.7 \%)$ of $>7$ drugs. Eleven (31.4\%) patients were taking beta-blockers.

The neurological examination was normal in all patients. Chest computed tomography showed single or multiple ground-glass and/or consolidative lung opacities consistent with interstitial pneumonia in all patients. Electrocardiogram showed corrected QT interval at rest ranging 409-511 ms (mean 451 \pm 30 ; median 449.5; interquartile range 433-474), PR interval ranging 104-220 ms (mean 161+35.5; median 153; interquartile range 136.5-195.5), and QRS complex duration ranging 66-134 ms (mean 95 \pm 18 ; median 93; interquartile range 83-105.5), which were nearly within normal values. Initial arterial blood gas analysis showed low $\mathrm{pO} 2$, $\mathrm{pCO}$, and $\mathrm{P} / \mathrm{F}$ ratio consistent with hypocapnic hypoxemia in most patients (table 1 ). However, patients did not show compensatory heart rate increase (fig. 1). Such mechanism likely underlay the occurrence of syncope (Yasuma et al., 2000).

Cardiovascular and respiratory systems strongly interact to ensure adequate oxygen release to tissues and organs, and the balance between sympathetic and parasympathetic inputs predominantly regulates heart rate response. The increased compensatory tachycardia response to hypoxia induces higher cardiac output, while stroke volume remains unchanged.

SARS-CoV-2 viral coat expresses the $S$ protein that contains a receptor-binding region with high affinity for the extracellular domain of angiotensin-converting enzyme-2 (ACE2) receptor. Binding leads to ACE2 internalization. It has been shown that the loss of ACE2 at cell surface could precipitate existing cardiovascular, kidney and brain diseases (South et al., 2020). The baroreceptor reflex control of heart rate is regulated by the brain renin-angiotensin system in the nucleus of the solitary tract (NTS) of the brainstem, where ACE2 is expressed (Doobay et al., 2007). Increased ACE2 activity in the brainstem decreases baroreflex sensitivity and vagal tone, and increases sympathetic output and heart rate (Mukerjee et al., 2019). Conversely, experimental injection of ACE2 antagonist in rat NTS increased sensitivity of the baroreceptor reflex leading to bradycardia response (Diz et al., 2008).

In patients experiencing syncope, SARS-CoV-2 could have caused ACE2 internalization in the NTS, thus altering the baroreflex response and inhibiting the compensatory increase of heart rate during acute hypocapnic hypoxemia.

\section{References}

Benelli, G., Buscarini, E., Canetta, C., La Piana, G., Merli, G., Scartabellati, A., Viganò, G., Sfogliarini, R., Melilli, G., Assandri, R., Cazzato, D., Rossi, D.S., Usai, S., Caldarelli, G., Gili, T., Tramacere, I., Pellegata, G., Lauria, G. 2020. SARS-COV-2 comorbidity network and outcome in hospitalized patients in Crema, Italy. https://doi.org/10.1101/2020.04.14.20053090.

Diz, D.I., Garcia-Espinosa, M.A., Gegick, S., Tommasi, E.N., Ferrario, C.M., Ann Tallant, E., Chappell, M.C., Gallagher, P.E. 2008. Injections of angiotensin-converting enzyme 2 inhibitor MLN4760 into nucleus tractus solitarii reduce baroreceptor reflex sensitivity for heart rate control in rats. Exp Physiol 93, 694-700.

Doobay, M.F., Talman, L.S., Obr, T.D., Tian, X., Davisson, R.L., Lazartigues, E. 2007. Differential expression of neuronal ACE2 in transgenic mice with overexpression of the brain renin-angiotensin system. Am J Physiol Regul Integr Comp Physiol 292, R373-381.

Ebrille, E., Lucciola, M.T., Amellone, C., Ballocca, F., Orlando, F., Giammaria, M. 2020. Syncope as the presenting symptom of COVID-19 infection. HeartRhythm Case Rep.

Mukerjee, S., Gao, H., Xu, J., Sato, R., Zsombok, A., Lazartigues, E. 2019. ACE2 and ADAM17 Interaction Regulates the Activity of Presympathetic Neurons. Hypertension 74, 1181-1191.

South, A.M., Diz, D.I., Chappell, M.C. 2020. COVID-19, ACE2, and the cardiovascular consequences. Am J Physiol Heart Circ Physiol 318, H1084-H1090. 
medRxiv preprint doi: https://doi.org/10.1101/2020.05.29.20114751; this version posted June 2, 2020. The copyright holder for this preprint (which was not certified by peer review) is the author/funder, who has granted medRxiv a license to display the preprint in perpetuity. All rights reserved. No reuse allowed without permission.

Tape, C., Byrd, K.M., Aung, S., Lonks, J.R., Flanigan, T.P., Rybak, N.R. 2020. COVID-19 in a Patient Presenting with Syncope and a Normal Chest X-ray. R I Med J (2013) 103, 50-51.

Yasuma, F., Hayano, J.I. 2000. Impact of acute hypoxia on heart rate and blood pressure variability in conscious dogs. Am J Physiol Heart Circ Physiol 279, H2344-2349. 
medRxiv preprint doi: https://doi.org/10.1101/2020.05.29.20114751; this version posted June 2, 2020. The copyright holder for this preprint (which was not certified by peer review) is the author/funder, who has granted medRxiv a license to display the preprint in perpetuity. All rights reserved. No reuse allowed without permission.

\begin{tabular}{|c|c|}
\hline & $\begin{array}{l}\text { Patients with syncope } \\
\qquad(\mathrm{n}=35)\end{array}$ \\
\hline \multicolumn{2}{|l|}{ Age, years } \\
\hline Mean (SD) & $74(12)$ \\
\hline Median (range) & $76(44-93)$ \\
\hline \multicolumn{2}{|l|}{ Sex, $n(\%)$} \\
\hline Male & $24(69 \%)$ \\
\hline Female & $11(31 \%)$ \\
\hline Repeated syncope, n (\%)* & $9(26 \%)$ \\
\hline \multicolumn{2}{|l|}{$\mathrm{SO}_{2}$} \\
\hline Mean (SD) & $94(8)$ \\
\hline Median (range) & $96(52-99)$ \\
\hline \multicolumn{2}{|l|}{$\mathrm{pCO}_{2}$} \\
\hline Mean (SD) & $32(40)$ \\
\hline Median (range) & $32(21-40)$ \\
\hline $\mathrm{pCO}_{2}<35, \mathrm{n}(\%)$ & $27(77 \%)$ \\
\hline \multicolumn{2}{|l|}{$\mathrm{pO}_{2}$} \\
\hline Mean (SD) & $64(8)$ \\
\hline Median (range) & $64(51-81)$ \\
\hline $\mathrm{pO} 2<60, \mathrm{n}(\%)$ & $12(34 \%)$ \\
\hline \multicolumn{2}{|l|}{$\mathrm{FiO}_{2}$} \\
\hline Mean (SD) & $0.23(0.05)$ \\
\hline Median (range) & $0.21(0.21-0.40)$ \\
\hline \multicolumn{2}{|l|}{$\mathrm{P} / \mathrm{F}$} \\
\hline Mean (SD) & $284(60)$ \\
\hline Median (range) & 289 (139-379) \\
\hline $\mathrm{P} / \mathrm{F} \leq 300, \mathrm{n}(\%)$ & $20(57 \%)$ \\
\hline \multicolumn{2}{|l|}{$\mathrm{HR}$} \\
\hline Mean (SD) & $87(17)$ \\
\hline Median (range) & $88(50-120)$ \\
\hline $\mathrm{FC}>100, \mathrm{n}(\%)$ & $6(17 \%)$ \\
\hline \multicolumn{2}{|l|}{ MAP } \\
\hline Mean (SD) & $90(16)$ \\
\hline Median (range) & $87(56-133)$ \\
\hline
\end{tabular}

Table 1 SARS-COV-2 patients presenting with syncope initial features. $\mathrm{SO}_{2}$ is oxygen saturation; $\mathrm{pCO} 2$ and $\mathrm{pO} 2$ are partial pressure of $\mathrm{CO} 2$ and $\mathrm{O} 2$; FiO2 is fraction of inspired oxygen; $P / F$ is the ratio of arterial oxygen partial pressure (PaO2) to fractional inspired oxygen (FiO2); HR is heart rate; MAP is mean arterial pressure [diastolic $+1 / 3$ (systolic- diastolic)]. 
medRxiv preprint doi: https://doi.org/10.1101/2020.05.29.20114751; this version posted June 2, 2020. The copyright holder for this preprint (which was not certified by peer review) is the author/funder, who has granted medRxiv a license to display the preprint in perpetuity. All rights reserved. No reuse allowed without permission.

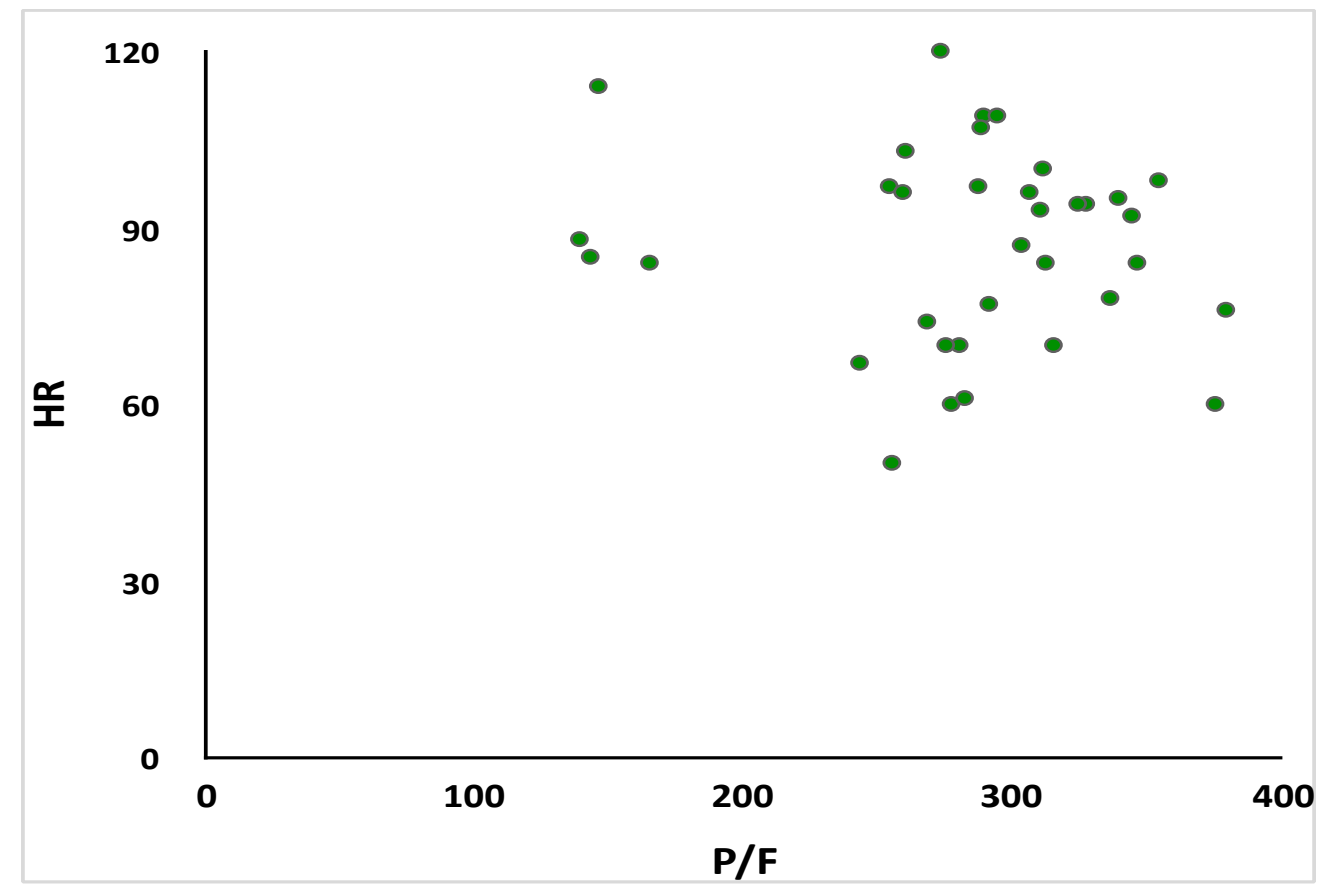

Figure 1 Scatter plot showing no correlation ( $r h o=-0.04, p=0.84$ ) between heart rate (HR) and ratio of (pO2) arterial oxygen partial pressure to (FiO2) fractional inspired oxygen (P/F). 
Kindly confirm that your manuscript meets the following criteria by marking an ' $x$ ' in each appropriate box on the left. Alternatively, print the form, fill it in and scan it for submission with your manuscript files.

\begin{tabular}{|c|c|}
\hline & $\begin{array}{l}\text { The manuscript is not, either in part or whole, under active consideration by any other journal, will } \\
\text { not be submitted for review to another journal until European Journal of Neurology makes an } \\
\text { editorial decision on it, and has not been published in any other journal in either hard-copy or } \\
\text { electronic format. } \\
\text { Note: Abstracts and press reports published in connection with scientific meetings are not } \\
\text { considered as publications. }\end{array}$ \\
\hline & $\begin{array}{l}\text { All co-authors have made a substantial contribution to the design, data collection and analysis of } \\
\text { the research and the drafting of the manuscript and have reviewed and accepted the contents of } \\
\text { the manuscript prior to its submission. }\end{array}$ \\
\hline & $\begin{array}{l}\text { There has been no ghost writing by anyone not named as a co-author. The manuscript is free from } \\
\text { falsification, fabrication and plagiarism. }\end{array}$ \\
\hline & $\begin{array}{l}\text { If the study involved people, human tissues, medical records or death certificates even } \\
\text { retrospectively, the Methods/Patients section includes the full name of the institutional review } \\
\text { board or ethics committee that approved the research protocol. } \\
\text { Note: If no such approval was needed according to the local regulations, that is explained in the } \\
\text { Methods section. }\end{array}$ \\
\hline$N \cdot A$ & $\begin{array}{l}\text { If the study involved a specific intervention purely for research - even a questionnaire - the } \\
\text { Methods/Patients section indicates that the study subjects or their next-of-kin gave informed } \\
\text { consent for their participation. }\end{array}$ \\
\hline & $\begin{array}{l}\text { Completed ICMJE disclosure forms for all authors are submitted along with the manuscript files. } \\
\text { The manuscript includes a section titled 'Disclosure of conflict of interest'. This section details any } \\
\text { financial relationships that the authors may have with the company whose drug or other product } \\
\text { is described in the manuscript. Where no such relationship exists, the section indicates 'None'. }\end{array}$ \\
\hline$N \cdot A$ & $\begin{array}{l}\text { If the research being reported has received funding or other outside support, the manuscript } \\
\text { includes a section titled 'Acknowledgements'. This section details the sources of funding and } \\
\text { acknowledges the outside support. }\end{array}$ \\
\hline N.A & $\begin{array}{l}\text { If the manuscript reports the results of a randomized clinical trial, the details of trial registration } \\
\text { are given in a section titled 'Trial registration'. }\end{array}$ \\
\hline & Optional comments: \\
\hline & Name/signature of the guarantgr: ${ }_{\text {G }}$ S $A$ \\
\hline
\end{tabular}

